 \\ ISSN: $2339-2479$ \\ DOI: $10.14692 /$ jfi.9.2.53
}

\title{
Potensi Minyak Atsiri untuk Mengendalikan Potyvirus pada Tanaman Nilam
}

\author{
Potential of Essential Oil to Control Potyvirus \\ on Patchouli Plant \\ Maya Mariana, Rita Noveriza* \\ Balai Penelitian Tanaman Rempah dan Obat, Bogor 16111
}

\begin{abstract}
ABSTRAK
Salah satu masalah dalam budi daya nilam ialah penyakit mosaik yang disebabkan oleh virus. Virus yang dominan menyebabkan penyakit mosaik pada tanaman nilam ialah Potyvirus. Penyakit mosaik telah tersebar di seluruh sentra produksi nilam di Jawa dan Sumatera yang dapat menurunkan terna basah, terna kering, kadar minyak dan patchouli alcohol. Bahan aktif dari minyak atsiri yang dilaporkan sebagai antivirus, yaitu $\beta$-caryphyllene, linaly asetat, sabinene, timol, karvakrol, kariofilena oksida, linalool, karvon dan geraniol. Penelitian ini bertujuan menentukan potensi dan konsentrasi minyak atsiri yang dapat menekan perkembangan Potyvirus asal tanaman nilam. Penelitian ini menggunakan minyak atsiri cengkih dan serai wangi. Minyak disemprotkan ke permukaan daun nilam dan dibiarkan selama 24 jam, kemudian sap tanaman terinfeksi Potyvirus diinokulasi secara mekanis. Minyak serai wangi pada konsentrasi $1.2 \%$ memberikan jumlah lesio lebih sedikit dibandingkan dengan perlakuan yang lain pada hari ketiga setelah inokulasi. Persentase penghambatan minyak serai wangi terhadap Potyvirus asal nilam Bogor pada konsentrasi 1.2\% mencapai $89.78 \%$. Hal ini menunjukkan minyak serai wangi memiliki potensi menekan perkembangan Potyvirus pada tanaman nilam.
\end{abstract}

Kata kunci: antivirus, cengkih, minyak serai wangi, penyakit mosaik

\begin{abstract}
One of the problems in the cultivation of patchouli is a mosaic disease caused by viruses. The dominant virus causing mosaic disease on patchouli plant belongs to Potyvirus group. Mosaic disease has spread throughout the central patchouli production in Java and Sumatra which can lower the wet herb, dried herb, oil and patchouli alcohol levels. The active contain of essential oils are reported as anti virus such as $\beta$ - caryphyllene, thymol, carvacrol, caryophyllene oxide, sabinene, linalool, linaly acetate, carvone and geraniol. The research aims to determine the potential and concentration of essential oils that can suppress Potyvirus. The research used essential oil from clove and citronella. Oil was sprayed onto the leaves surface and left for $24 \mathrm{hr}$, then sap from Potyvirus infected plant was mechanically inoculated. Citronella oil concentration of $1.2 \%$ have less number of lesions compared to the other treatments on the third day after inoculation. The percentage inhibition of citronella oil to Potyvirus on $1.2 \%$ concentration reached $89.78 \%$. This showed that citronella oil has potential to suppress the development of Potyvirus in patchouli plant.
\end{abstract}

Key words: antiviral, citronella oil, clove, mosaic disease

*Alamat penulis korespondensi: Balai Penelitian Tanaman Rempah dan Obat. Jalan Tentara Pelajar No 3, Bogor 16111 Tel: 0251-8321879, Faks: 0251-8327010,Surel: rita_noveriza2000@yahoo.com,maya.marliana@ymail.com 


\section{PENDAHULUAN}

Tanaman nilam (Pogostemon cablin) merupakan tanaman penghasil minyak atsiri di Indonesia. Salah satu masalah dalam budi daya nilam ialah adanya penyakit mosaik yang disebabkan oleh virus. Virus dominan yang menginduksi gejala mosaik pada nilam adalah Potyvirus. Hasil identifikasi molekuler menunjukkan bahwa spesies Potyvirus penyebab penyakit mosaik nilam di Indonesia ialah Telosma mosaic virus (TeMV) (Noveriza 2013). Penyakit mosaik telah tersebar di seluruh sentra produksi nilam di Jawa dan Sumatera, dengan rata-rata tingkat kejadian infeksi virus berdasarkan hasil enzym linked immunosorbent assay (ELISA) mencapai $55.5 \%$ (Noveriza 2013). Penyakit mosaik menyebabkan penurunan produksi terna basah, terna kering, kadar minyak dan patchouli alcohol berturut-turut mencapai $34.65 \%, 40.42 \%, 9.09 \%$, dan $5.06 \%$ (Noveriza et al. 2012a).

Bahan alami yang dihasilkan oleh tanaman (seperti minyak atsiri) mungkin dapat digunakan dalam pengendalian penyakit tanaman yang disebabkan oleh virus. Uji toksikologi menunjukkan bahwa minyak atsiri tidak beracun dan dinyatakan aman terhadap mamalia dan ikan (Koul et al. 2008). Oleh sebab itu, minyak atsiri diterima oleh konsumen sebagai pestisida nabati untuk mengendalikan hama dan penyakit tanaman.

Minyak atsiri dan ekstrak tanaman mengandung zat-zat aktif yang dapat menghambat infeksi virus. Minyak atsiri dan bahan aktifnya, seperti thymol, $\beta$-caryophyllene, caryophyllene oxide, efektif menghambat perkembangan Cucumber mosaic virus (CMV) dan Tobacco mosaic virus (TMV). Minyak atsiri dari Melaleuca alternifolia pada konsentrasi 100, 250, dan 500 ppm dilaporkan efektif untuk menurunkan jumlah lesio lokal dari TMV pada Nicotiana glutinosa (Bishop 1995). Begitu juga minyak dari Ageratum conyzoides, Callistemon lanceolatus, Carum copticum, Ocimum sanctum, dan Peperomia pellucid efektif menghambat aktivitas Cowpea mosaic virus (CPMV), Mungbean mosaic virus (MBMV), Bean common mosaic virus
(BCMV) dan Southern bean mosaic virus (SBMV). Ocimum sanctum pada konsentrasi 3000 ppm memberikan penghambatan tertinggi terhadap CMV, MBMV, BCMV, dan SBMV berturut-turut, yaitu 89.6\%,0\%, 92.7\%, dan 88.2\% (Rao et al. 1986) dan terhadap Tobacco mosaic virus (TMV) sebesar $62 \%$. Pada daun wortel yang segar diidentifikasi 20 senyawa yang bisa bersifat sebagai antivirus, di antaranya sabinene, linalyl asetat, linalool, dan karvon (Khanna et al. 1990).

Beberapa penelitian telah dilakukan untuk mengendalikan Tomato spotted wilt virus (TSWV) dan trips (vektor dari TSWV) di lapangan dengan menggunakan minyak atsiri, seperti geraniol, serai (Cymbopogon flexuosus), dan tea tree (M. alternifolii) yang dikombinasikan dengan kaolin, dapat mengurangi insiden penyakit sebesar $32-51 \%$ pada tanaman tomat. Hasil yang didapat kurang lebih sama jika dibandingkan dengan menggunakan insektisida kimia sintetik (Reitz et al. 2008). Penelitian ini bertujuan menentukan potensi dan konsentrasi minyak atsiri yang dapat menekan perkembangan Potyvirus asal tanaman nilam.

\section{BAHAN DAN METODE}

\section{Perbanyakan Sumber Inokulum dan Perbanyakan Tanaman Uji}

Isolat murni Potyvirus berasal dari tanaman nilam di Bogor. Virus ini diperbanyak pada tanaman nilam. Tanaman uji yang digunakan ialah Chenopodium amaranticolor.

\section{Uji Minyak Atsiri sebagai Antivirus}

Minyak atsiri yang digunakan adalah minyak serai wangi dan cengkih. Minyak atsiri disemprotkan ke permukaan daun dan dibiarkan selama 24 jam, kemudian diolesi sap Potyvirus $(1: 1 \mathrm{v} / \mathrm{v})$.

Penelitian ini disusun dengan 7 perlakuan dan 5 ulangan. Perlakuan tersebut ialah minyak cengkih dengan konsentrasi $0.7 \%$ dan $1.2 \%$, minyak serai wangi $(0.7 \%$ dan $1.2 \%)$, pelarut (Tween 80), asimbo (produk bahan aktif minyak atsiri) konsentrasi 2\%, dan air sebagai kontrol. 
Pengamatan yang dilakukan ialah waktu pertama kali munculnya gejala dengan menghitung jumlah lesio lokal pada tanaman uji. Jumlah lesio dihitung setiap hari sampai tidak dapat diamati karena gejala sudah menyatu. Persentase penghambatan masingmasing perlakuan dihitung dan dibandingkan dengan tanaman kontrol. Persentase penghambatan dihitung menggunakan rumus (Valerija et al. 2010):

$$
\mathrm{IP}=\frac{\mathrm{CK}-\mathrm{A}}{\mathrm{CK}} \times 100 \% \text {, dengan }
$$

IP, persentase penghambatan; $\mathrm{CK}$, rata-rata lesio kontrol; A, rata-rata lesio perlakuan.

\section{Deteksi Virus dengan Indirect ELISA}

Deteksi Potyvirus pada sampel daun dari tanaman $C$. amaranticolor dilakukan dengan indirect-ELISA menggunakan antiserum Potyvirus mengikuti metode Deutsche Sammlung von Mikroorganismen und Zekkulturen GmbH (DSMZ) (Clark dan Adams 1977). Sebanyak 0.2 g daun C. amaranticolor digerus dalam $1 \mathrm{~mL}$ buffer coating yang mengandung M DIECA 0.05 sehingga menjadi cairan ekstrak. Selanjutnya, $100 \mu \mathrm{L}$ cairan ekstrak diisikan pada lubang plat mikrotiter dan diinkubasi pada suhu $4{ }^{\circ} \mathrm{C}$ selama semalam, dicuci dengan PBS-T (bufer fosfat ditambah Tween-20) sebanyak 5 kali. Selanjutnya lubang plat diisi dengan $100 \mu \mathrm{L}$ larutan skim milk 2\% dalam PBS-T dan diinkubasi pada suhu $37{ }^{\circ} \mathrm{C}$ selama 30 menit. Selanjutnya, lubang plat mikrotiter diisi $100 \mu \mathrm{L}$ antiserum Potyvirus (DSMZ), dengan pengenceran $10^{-3}$ dalam bufer konjugat dan diinkubasi pada suhu $37^{\circ} \mathrm{C}$ selama 2-4 jam. Setelah dicuci dengan PBS-T, lubang plat diisi $100 \mu \mathrm{L}$ konjugat RaM-AP yang diencerkan $10^{-3}$ dalam bufer konjugat, dan diinkubasi selama 2 jam pada suhu $37^{\circ} \mathrm{C}$. Setelah dicuci dengan PBS-T, lubang plat diisi substrat p-nitrofenil fosfat dan diinkubasi selama 30 60 menit pada suhu ruang. Hasil ELISA diukur nilai absorbansinya menggunakan micro-plate reader pada panjang gelombang $405 \mathrm{~nm}$.

\section{HASIL}

\section{Kondisi Umum Tanaman}

Semua perlakuan tanaman percobaan yang diinokulasi Potyvirus menunjukkan adanya gejala lesio yang terbentuk setelah 3 hari inokulasi. Munculnya gejala lesio pada setiap perlakuan menunjukan adanya infeksi virus pada semua tanaman. Jumlah lesio yang terbentuk setelah 3 hari berbeda-beda pada masing-masing perlakuan (Gambar 1).

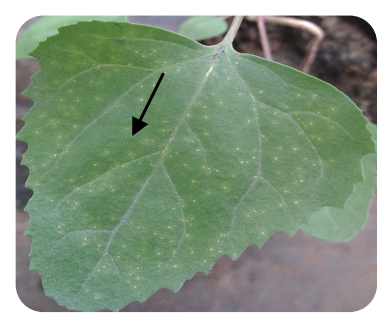

a

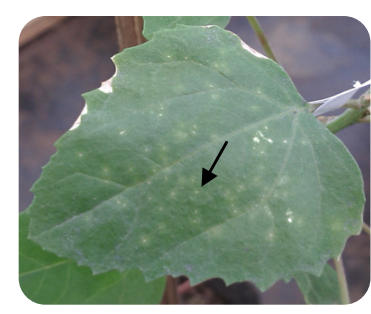

e

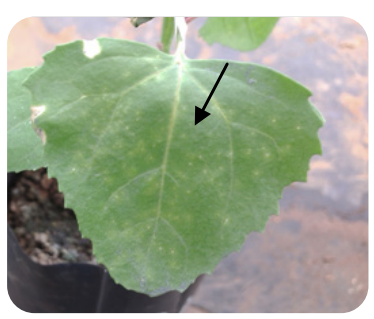

b

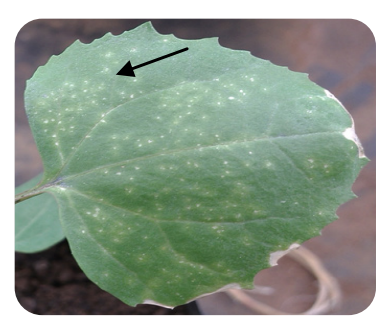

C

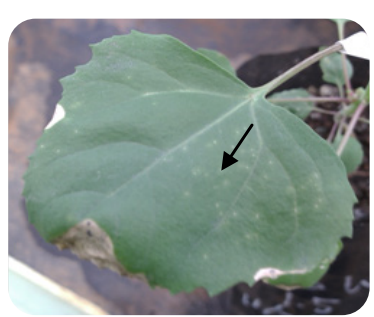

d

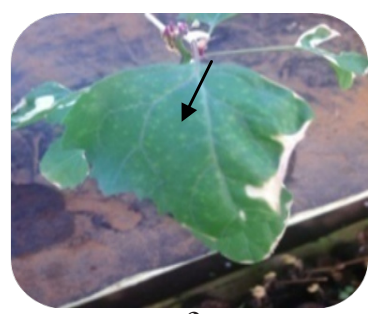

f

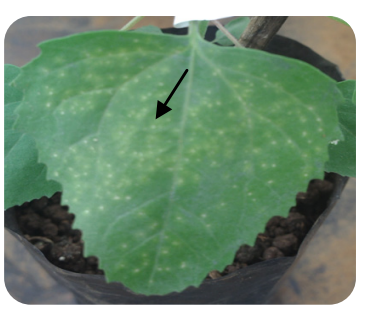

g

Gambar 1 Gejala infeksi Potyvirus berupa lesio pada tanaman uji Chenopodium amaranticolor. a, Minyak cengkih $0.7 \%$; b, Minyak cengkih $1.2 \%$; c, Minyak serai wangi $0.7 \%$; d, Minyak serai wangi konsentrasi 1.2\%; e, Tween 80; f, Asimbo; g, Kontrol. 


\section{Pengaruh Minyak Atsiri pada Tanaman Uji berdasarkan Gejala Lesio}

Uji minyak atsiri menunjukkan bahwa jumlah lesio yang terbentuk di permukaan daun pada perlakuan minyak serai wangi konsentrasi $1.2 \%$, minyak cengkih konsentrasi $1.2 \%$, Tween 80 , dan asimbo konsentrasi $2 \%$ berbeda nyata dibandingkan dengan kontrol (Tabel 1). Minyak serai wangi konsentrasi $1.2 \%$ memiliki rata-rata jumlah lesio terkecil di antara semua perlakuan dan berbeda nyata dibandingkan dengan kontrol.

\section{Persentase Penghambatan pada Tanaman Uji}

Minyak serai wangi pada konsentrasi $1.2 \%$ memiliki persentase penghambatan tertinggi dibandingkan dengan perlakuan yang lain. Persentase penghambatan mencapai $89.78 \%$, dengan jumlah lesio yang lebih sedikit dibandingkan dengan perlakuan yang lain (Gambar 2).

\section{Deteksi Virus secara Serologi}

Deteksi virus dengan ELISA menunjukkan hasil yang positif adanya Potyvirus pada tanaman uji. Hal ini dapat ditandai dengan hasil pembacaan nilai absorban pada perlakuan 1.5 kali lebih besar daripada kontrol (Tabel 2).

\section{PEMBAHASAN}

Perlakuan minyak serai wangi konsentrasi $1.2 \%$, menyebabkan jumlah lesio yang muncul lebih sedikit dan berbeda nyata dibandingkan dengan perlakuan yang lain (pada hari ketiga). Persentase penghambatan minyak serai wangi pada konsentrasi $1.2 \%$ paling tinggi dibandingkan perlakuan lainnya. Hal ini menunjukkan bahwa minyak serai wangi memiliki potensi menekan perkembangan Potyvirus.

Berdasarkan penelitian yang dilakukan oleh Balai Penelitian Tanaman Buah, minyak serai wangi dapat digunakan untuk

Tabel 1 Jumlah lesio yang terbentuk pada tanaman uji Chenopodium amaranticolor pada hari ketiga setelah inokulasi

\begin{tabular}{lc}
\hline Perlakuan (konsentrasi) & Jumlah lesio (\%)* \\
\hline Minyak Cengkih $(0.7 \%)$ & $73.15 \mathrm{a}$ \\
Minyak Cengkih $(1.2 \%)$ & $39.15 \mathrm{~b}$ \\
Minyak Serai Wangi $(0.7 \%)$ & $66.00 \mathrm{a}$ \\
Minyak Serai Wangi $(1.2 \%)$ & $7.90 \mathrm{c}$ \\
Tween $80(2 \%)$ & $21.50 \mathrm{bc}$ \\
Asimbo (2\%) & $21.45 \mathrm{bc}$ \\
Kontrol & $77.30 \mathrm{a}$ \\
\hline
\end{tabular}

*Angka pada kolom yang sama yang diikuti oleh huruf yang sama tidak berbeda nyata berdasarkan uji DMRT pada taraf $\alpha 0.05$

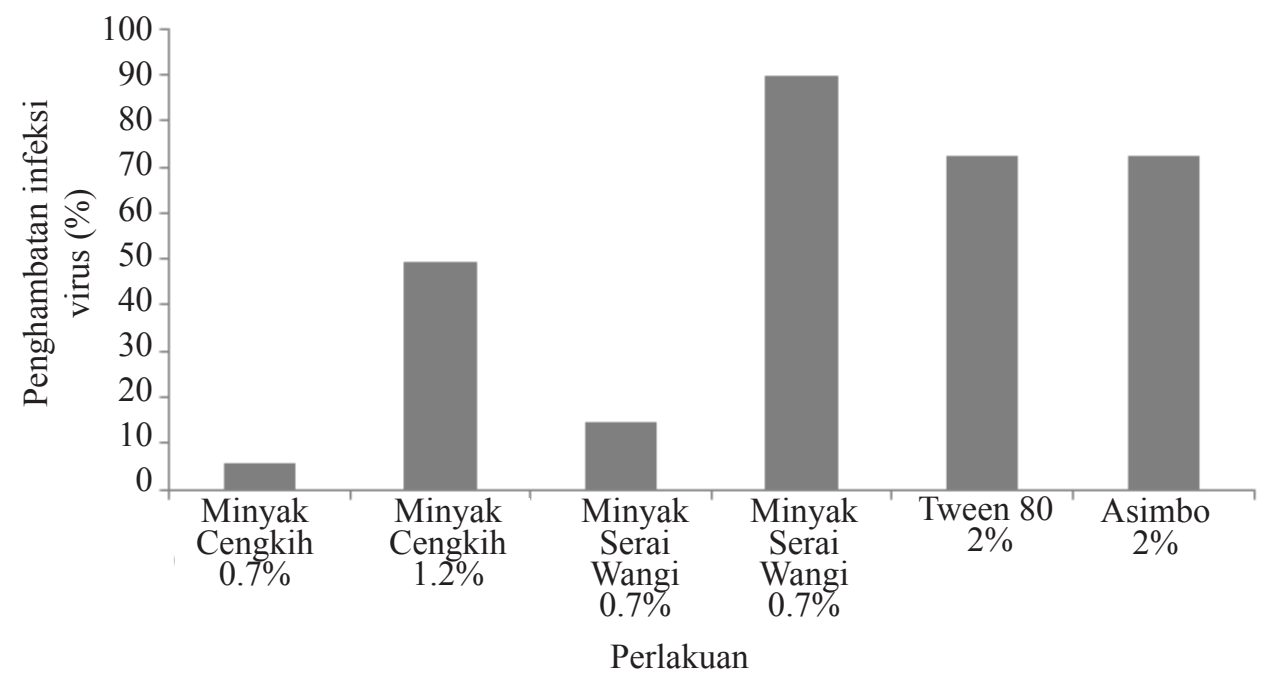

Gambar 2 Persentase penghambatan minyak atsiri terhadap infeksi Potyvirus pada tanaman uji Chenopodium amaranticolor pada hari ketiga setelah inokulasi. 
Tabel 2 Hasil uji Potyvirus dengan Indirect ELISA

\begin{tabular}{lcc}
\hline \multirow{2}{*}{ Perlakuan (konsentrasi) } & \multicolumn{2}{c}{ ELISA } \\
\cline { 2 - 3 } & Nilai absorban & Hasil uji \\
\hline Minyak Cengkih $(0.7 \%)$ & 0.736 & positif \\
Minyak Cengkih $(1.2 \%)$ & 0.185 & positif \\
Minyak Serai Wangi $(0.7 \%)$ & 0.374 & positif \\
Minyak Serai Wangi $(1.2 \%)$ & 0.078 & positif \\
Tween $80(2 \%)$ & 0.048 & positif \\
Asimbo $(2 \%)$ & td & td \\
Kontrol positif & 0.162 & positif \\
Kontrol negatif & 0.002 & negatif \\
Bufer & 0.000 & negatif \\
\hline
\end{tabular}

td, tidak diuji

mengendalikan kutu daun. Oleh karena itu, minyak serai wangi berpotensi untuk menekan perkembangan TeMV (Potyvirus) dan sekaligus juga dapat menurunkan populasi Aphis gossypii sebagai vektor TeMV pada tanaman nilam (Noveriza 2013). Geraniol yang dikombinasikan dengan kaolin dapat mengurangi insidensi penyakit pada tanaman tomat yang disebabkan oleh TSWV yang berkisar 32-51\% (Reitz et al. 2008). Salah satu komponen kimia penyusun minyak serai wangi adalah geraniol (Ganjewala 2009).

Minyak serai wangi dapat berfungsi sebagai antibakteri dan antivirus. Senyawa pada minyak serai wangi tersusun oleh beberapa senyawa-senyawa fenol, senyawa saponin, flavonoid dan terpen yang diduga memiliki daya hambat terhadap bakteri (Suprianto 2008). Dalam penelitian ini belum diketahui secara pasti senyawa kimia yang berperan dalam penghambatan munculnya lesio pada tanaman uji sehingga dapat menekan perkembangan Potyvirus.

\section{UCAPAN TERIMA KASIH}

Penulis mengucapkan terima kasih kepada Asep dan Sugiyanto dalam pelaksanaan penelitian.

\section{DAFTAR PUSTAKA}

Bishop CD. 1995. Antiviral activity of the essential oil of Melaleuca alternifolia (Maiden \& Betche) cheel (Teatree) against
Tobacco mosaic virus. J Essen Oil Res. 7:641-648. DOI: http://dx.doi.org/10.108 0/10412905.1995.9700519.

Clark MF, Adams AN. 1977. Characteristics of the microplate method of enzyme-linked immunosorbent assay for the detection of plant viruses. J Gen Virol. 34:475-483. DOI: http://dx.doi.org/10.1099/0022-131734-3-475.

Ganjewala D. 2009. Cymbopogon essential oil: Chemical composition and bioactivities. International Journal of Essential Oil Therapeutics. 3:56-65.

Khanna RK, Sharma OS, Singh A, Battacharya SC, Sen N, Sethi KL.1990.The essential oil from leaves of Daucus carota Linn.var sativa. Chem Anal Struc 14:173-176.

Koul O, Walia S,Dhaliwal GS. 2008. Essentials oils as green pesticides: Potential and constraints. Biopestic Int. 4(1):63-84.

Noveriza R. 2013. Penyakit mosaik pada tanaman nilam dan identifikasi Telosma mosaic virus (TeMV) yang berasosiasi serta pengendaliannya [disertasi]. Bogor (ID): Institut Pertanian Bogor.

Noveriza R, Suastika G, Hidayat SH, Kartosuwondo U. 2012a. Pengaruh infeksi virus mosaik terhadap produksi dan kadar minyak tiga varietas nilam. Bul Littro. 23(1):93-101.

Noveriza R, Suastika G, Hidayat SH, Kartosuwondo U. 2012b. Penularan Potyvirus penyebab penyakit mosaik pada tanaman nilam melalui vektor Aphis gossypii. J Fitopatol Indones. 8(3):65-72. 
Rao GP, Pandey AK, Shukla K. 1986. Essential oils of some higher plants vis a-vis some legume viruses. Indian Perfume. 30(4):483-486.

Reitz SR, Maiorino G, Olson S, Sprenkel R, Crescenzi A, Momol MT. 2008. Interesting plant essential oils and kaolin for the sustainable management of thrips and Tomato spotted wilt virus on tomato. Plant Dis. 92:878-886. DOI: http://dx.doi. org/10.1094/PDIS-92-6-0878.
Suprianto. 2008. Potensi ekstrak sereh wangi (Cymbopogon nardus L.) sebagai anti Streptococcus mutans [skripsi]. Bogor (ID): Institut Pertanian Bogor.

Valerija D, Nada B, Elma V, Dubravka C. 2010. Antiphytoviral activity of satureja montana L. ssp. variegate (host) $\mathrm{P}$. W. ball essential oil and phenol compounds on CMV and TMV. Molecules. 15:67136721. DOI: http://dx.doi.org/10.3390/ molecules 15106713 . 